\title{
Review Article \\ Potential Renoprotective Agents through Inhibiting CTGF/CCN2 in Diabetic Nephropathy
}

\author{
Songyan Wang, ${ }^{1,2}$ Bing Li, ${ }^{2}$ Chunguang Li, ${ }^{3}$ Wenpeng Cui, ${ }^{1}$ and Lining Miao \\ ${ }^{1}$ Department of Nephrology, Second Hospital of Jilin University, Changchun 130041, China \\ ${ }^{2}$ Department of Nephrology, Jilin Province People's Hospital, Changchun 130021, China \\ ${ }^{3}$ Department of Urology, The 2nd Hospital of Changchun, Changchun 130061, China \\ Correspondence should be addressed to Lining Miao; miaolining55@163.com
}

Received 29 September 2014; Revised 28 February 2015; Accepted 25 March 2015

Academic Editor: Bagher Larijani

Copyright (C) 2015 Songyan Wang et al. This is an open access article distributed under the Creative Commons Attribution License, which permits unrestricted use, distribution, and reproduction in any medium, provided the original work is properly cited.

\begin{abstract}
Diabetic nephropathy (DN) is the leading cause of end-stage renal disease (ESRD). The development and progression of DN might involve multiple factors. Connective tissue growth factor (CCN2, originally known as CTGF) is the one which plays a pivotal role. Therefore, increasing attention is being paid to CCN2 as a potential therapeutic target for DN. Up to date, there are also many drugs or agents which have been shown for their protective effects against DN via different mechanisms. In this review, we only focus on the potential renoprotective therapeutic agents which can specifically abolish CCN2 expression or nonspecifically inhibit CCN2 expression for retarding the development and progression of $\mathrm{DN}$.
\end{abstract}

\section{Introduction}

Diabetes is one of the manifestations of metabolic syndrome, characterized by high blood glucose. Diabetic nephropathy $(\mathrm{DN})$, as one of the most severe chronic diabetic microvascular complications, is a leading cause of end-stage renal disease (ESRD), which may result in high morbidity and mortality [1]. The pathological features of DN include glomerular and tubuloepithelial hypertrophy, diffuse thickening of glomerular and tubular basement membranes, mesangial expansion, and extracellular matrix proteins accumulation in the mesangium and tubulointerstitium, which may finally lead to glomerulosclerosis and tubulointerstitial fibrosis. Many factors and molecules contribute to this pathophysiological process, such as chronic hyperglycemia (HG), transforming growth factor- $\beta 1$ (TGF- $\beta 1$ ), and advanced glycation end product (AGE) [2]. Among them, CCN2 appears to play an important role in the development of DN.

Connective tissue growth factor (CTGF/CCN2) is a cytokine which was firstly detected by Bradham from conditioned human umbilical vein endothelial cells in 1991 [3]. It is a $38 \mathrm{kD}$ cysteine-rich peptide that belongs to the emerging CCN (CYR61, CTGF, NOV) family of multifunctional growth factors [4]. CCN2 is widely expressed in human tissues and organs, such as adult connective tissue, heart, brain, kidney, lung, liver, muscle, pancreas gland, and placenta, especially high in the kidney [5]. CCN2 was found in glomerular cells, tubular epithelial cells, and interstitial cells of the diabetic kidneys $[6,7]$. And CCN2 was upregulated in glomeruli of streptozotocin- (STZ-) induced diabetic rats with nephropathy and in primary human mesangial cells stimulated by glucose [8]. TGF- $\beta 1$, AGE, and angiotensin II (Ang II) also induced CCN2 expression under diabetic conditions [9-11]. The overproduction of CCN2 is suggested to play a pivotal role in some fibrotic diseases, including renal fibrosis [4].

Up to date, accumulating evidence suggests that $\mathrm{CCN} 2$ is not only a marker but also a key mediator in DN [12]. CCN2 contributes to the progress of DN through its function. CCN2 prevented matrix degradation through increasing the tissue inhibitor of matrix metalloproteinases 1 (TIMP-1) expression in diabetes [13]. CCN2 also caused epithelial to mesenchymal transition (EMT) in renal tubular cells in diabetes, leading to genesis of new fibroblasts in the renal interstitium $[14,15]$. Moreover, CCN2 promoted kidney fibroblast proliferation and ECM synthesis $[14,16]$. In vivo study showed that overexpression of CCN2 in podocytes worsened proteinuria 
TABLE 1: Agents for specific inhibition of CCN2 expression in diabetic nephropathy.

\begin{tabular}{|c|c|c|c|c|}
\hline Agents & Subjects & Treatment plan & Pathway & Outcomes \\
\hline \multirow[t]{2}{*}{ CTGF ASO [27] } & T1DM mice & $\begin{array}{l}20 \mathrm{mg} / \mathrm{kg} / 2 \mathrm{qw} \text { for } 16 \\
\text { weeks, subcutaneously }\end{array}$ & $\begin{array}{l}\text { Inhibition of } \\
\text { phosphorylation of } \mathrm{p} 38\end{array}$ & $\begin{array}{l}\text { CCN2 ASO reduced CCN2 expression } \\
\text { in the kidney of diabetic mice. } \\
\text { CCN2 ASO decreased proteinuria and } \\
\text { albuminuria. }\end{array}$ \\
\hline & $\mathrm{T} 2 \mathrm{DM} \mathrm{db} / \mathrm{db}$ mice & $\begin{array}{l}5,10 \text {, and } 20 \mathrm{mg} / \mathrm{kg} / 2 \mathrm{qw} \\
\text { for } 8 \text { weeks, } \\
\text { subcutaneously }\end{array}$ & $\begin{array}{l}\text { MAPK and CREB } \\
\text { pathway }\end{array}$ & $\begin{array}{l}\mathrm{CCN} 2 \text { ASO reduced serum creatinine } \\
\text { and attenuated urinary albuminuria } \\
\text { and proteinuria in diabetic mice. }\end{array}$ \\
\hline FG-3019 [32] & $\begin{array}{l}\text { T1DM, T2DM } \\
\text { patients }\end{array}$ & $\begin{array}{l}3 \text { or } 10 \mathrm{mg} / \mathrm{kg} / 2 \mathrm{qw}, \text { i.v., } \\
8 \text { wks }\end{array}$ & & $\begin{array}{l}\text { FG-3019 decreased urinary } \\
\text { albumin/creatinine ratio (ACR). }\end{array}$ \\
\hline
\end{tabular}

T1DM: type 1 diabetes mellitus; T2DM: type 2 diabetes mellitus; IG: intragastric; HK2: human renal proximal tubular epithelial cells.

and mesangial expansion through a functional impairment and loss of podocytes in mice with DN [17]. CCN-2 also contributed to the renal podocyte apoptosis [18]. In addition, $\mathrm{CCN}-2$ induced proinflammatory cytokines and led to early renal inflammation that preceded overt DN [19]. Remarkably the level of CCN2 expression was shown to be related with the severity and progression of renal fibrosis $[20,21]$ and it was proposed to be a useful molecular marker for the fibrotic response [22].

In recent years, with deeply understanding the role of CCN2 in fibrotic diseases including DN, CCN2 has become an important molecular marker in DN. And CCN2 has also become an index to auxiliarily verify the protective effect of some drugs or agents on diabetic nephropathy. In this review, we will summarize some potential renoprotective agents which can wholly or partly inhibit CCN2 for delaying the development and progression of diabetic kidney disease.

\section{Agents Which Can Specifically Inhibit CCN2 Expression in DN}

Based on the profibrotic role of $\mathrm{CCN} 2$ in diabetic nephropathy kidney disease, specific inhibitors of CCN2 such as CCN2 antisense oligonucleotides and neutralizing antibodies to CCN2 (FG-3019) have been studied (Table 1).

2.1. CCN2 Antisense Oligonucleotide (ASO). Previous studies demonstrated that blockade of CCN2 by antisense oligodeoxynucleotide (ODN) suppressed the production of fibronectin and type I collagen in renal fibroblasts exposed to TGF- $\beta 1$ and attenuated renal tubulointerstitial fibrosis [23]. Intravenous administration of CCN2 antisense ODN to subtotally nephrectomized TGF- $\beta 1$ transgenic mice led to marked reduction of $\mathrm{CCN} 2$ expression in the proximal tubular epithelial cells in the remnant kidney, accompanied by the decrease of matrix molecules, plasminogen activator inhibitor-1 (PAI-1), and tissue inhibitor of metalloproteinase1 , and with no change of TGF- $\beta 1$ levels [24]. CCN2 ASO also significantly decreased the expression of CCN2, fibronectin, fibronectin ED-A, and alphal (I) collagen genes in obstructed kidneys and without affection of TGF- $\beta$ gene upregulation in unilateral ureteral obstruction (UUO) rats [25]. These findings indicate the important role of the TGF- $\beta 1$-independent
CCN2 pathway in the development of renal interstitial fibrosis.

In addition, CCN2 ASO significantly attenuated angiotensin II- (Ang II-) induced epithelial mesenchymal transition (EMT), as evidenced by markedly decreased alphaSMA expression in human proximal tubular cell line (HK2) [26]. Guha et al. also evaluated the role of the specific blockade of CCN2 with a CCN2 ASO of novel chimeric chemistry (phosphorothioate and phosphodiester) in the progression of DN with a convenient biweekly dose schedule. In the streptozotocin- (STZ-) induced type $1 \mathrm{DN}$ model of mice, hyperglycemic animals treated with CCN2 ASO ( $20 \mathrm{mg} / \mathrm{kg} / 2 \mathrm{qw}$ ) for 4 months showed dramatically reduced CTGF expression in the kidney and decreased proteinuria and albuminuria. In type $2 \mathrm{DN}$ model of $\mathrm{db} / \mathrm{db}$ mice, administration of the CCN2 ASO for 8 weeks not only reduced serum creatinine and attenuated urinary albuminuria and proteinuria, but also decreased the expression of fibronectin, collagen (I and IV), and PAI-1 in the renal cortex through inhibiting phosphorylation of $\mathrm{p} 38 \mathrm{MAPK}$ and its downstream target CREB pathway. In vitro study showed that CCN2 ASO suppressed CCN2 and ECM protein expression in rat mesangial cells (MCs) exposed to high glucose [27]. These results suggest that specific blockade of $\mathrm{CCN} 2$ by a chimeric ASO is very promising in delaying the development and progress of diabetic nephropathy.

2.2. CCN2 Monoclonal Antibody-FG-3019. A human monoclonal antibody to CCN2, FG-3019, was initially used in treating a variety of tumors experimentally and showed antitumor activities in pancreas cancer [28], metastatic melanoma [29], and B-acute lymphoblastic leukemia (ALL) [30]. In addition, FG-3019 attenuated left ventricular remodeling and left ventricular dysfunction in pressure overloadinduced heart failure [31]. FG-3019 was also used in the experimental treatment of diabetic nephropathy. In a recent phase I clinical study, a human monoclonal antibody to CCN2, FG-3019, was intravenously administered to patients with microalbuminuric diabetic kidney disease (DKD) $n=$ 24) with the dose of 3 or $10 \mathrm{mg} / \mathrm{kg}$ every 2 weeks for four doses and then followed up at days 62 and 365 . The trial results showed that urinary albumin/creatinine ratio (ACR) reduced dramatically from $48 \mathrm{mg} / \mathrm{g}$ ACR (at baseline) to $20 \mathrm{mg} / \mathrm{g}$ ACR (day 56) $(P=0.027)$. There seems to be mild 
infusion adverse events on infusion day, but no significant drug-related side effect was observed over one year of followup [32]. Although reduction of albuminuria by FG-3019 in $\mathrm{DKD}$ patients was promising, the efficacy need to be further validated in a prospective, randomized, blinded study. Taken together, CTGF monoclonal antibody may become a potential therapeutic agent for diabetic kidney disease.

\section{Other Renoprotective Agents Which Can Nonspecifically Inhibit CCN2 Expression in DN}

Up to date, a wide variety of agents or drugs have shown their renoprotective properties through different mechanisms in diabetic nephropathy, but not all of the agents have the ability to inhibit the expression of connective tissue growth factor (CCN2). CCN2, as an important profibrotic cytokine, contributes to the development and progression of $\mathrm{DN}$. Therefore, in spite of the specific CCN2 inhibitors (CCN2 ASO and CCN2 monoclonal antibody-FG-3019), we also address several related agents which hold potential renoprotective effects against DN at least partly through inhibiting $\mathrm{CCN} 2$ expression. Some of the pathways between these renoprotective agents and CCN2 expression have been elucidated, but still several unknown related pathways/mechanisms need to be further studied. These agents include reninangiotensin- aldosterone system (RAAS) inhibitors, Rho Kinase Inhibitors, statins, mycophenolate mofetil, pyridone agents, glucagon-like peptide-1 (GLP-1) analog, and purple corn anthocyanins (PCA) (Table 2).

3.1. (Pro)Renin Receptor (PRR) Blockade. PRR is a new member of RAS. PRR acts by binding and activating prorenin through a single transmembrane domain [33]. It was reported that PRR was upregulated in kidneys of diabetic rats and renal mesangial cells (RMCs) induced by high glucose [34, 35]. A recent study has shown that (Pro)renin receptor (PRR) promoted the progression of diabetic nephropathy through enhanced TGF $\beta 1$ CCN2 signaling cascade, which was evidenced by administering PRR blockade in vivo and in vitro. High glucose-induced rapid PRR phosphorylation (30 min) was prior to upregulation of TGF $\beta 1$ and $\mathrm{CCN} 2$, and PRR phosphorylation was inhibited by prolonged handle region peptide (HRP) of prorenin, valsartan, and PRR siRNA treatments, which suggested that TGF $\beta$ CCN2 axis was activated by PRR signaling pathway. PRR blockade markedly decreased TGF- $\beta 1$ and CCN2 expression in diabetic animals and high glucose treated rat mesangial cells (RMCs). Angiotensin AT1 receptor blockade with valsartan got similar effects. Combined treatment with valsartan and PRR siRNA further decreased TGF $\beta 1$ and CCN2 expression, suggesting that AT1R and PRR may independently influence TGF $\beta 1$ CCN2 axis, or PRR upregulated TGF $\beta 1$ and CCN2 expression by promoting angiotensin II formation and stimulation of AT1R (Figure 1) [36]. Other studies also demonstrated that PRR blockade attenuated albuminuria in diabetic rats [37] and delayed the progression of diabetic nephropathy [38].
Taken together, the blockade of ATIR and PRR may be renoprotective through inhibiting TGF $\beta 1-\mathrm{CCN} 2$ expression.

3.2. Angiotensin II Receptor Blockade. It was reported that the intrarenal renin-angiotensin system (RAS) was aberrantly activated in the prediabetic stage and might promote the onset and development of later diabetic nephropathy [39]. Previous studies have reported that angiotensin II (Ang II) contributed to renal hypertrophy and subsequent renal fibrosis in the development of diabetic nephropathy [40]. CCN2 is also involved in renal hypertrophy induced by angiotensin (Ang II). It was reported that the expression of CCN2 was markedly upregulated in both glomeruli and tubuli of diabetic rats, and the extent of CCN2 expression closely correlated with the severity of renal hypertrophy, administration of irbesartan (IRB), or Ang II receptor antagonist significantly suppressed CCN2 expression in kidneys of diabetic rats [41, 42]. The in vitro study showed that angiotensin II (Ang II) significantly stimulated CCN2 expression in human proximal tubular cells (HK2 cells). Moreover, Ang II promoted the increase of HK2 cell size and arrested the cell cycle in the G0-G1 phase, which was notably reversed by cotreatment with CTGF ASO [41]. In addition, a three-year clinical study, including 71 hypertensive type 1 diabetic nephropathy patients who were treated with Losartan, demonstrated that Losartan markedly decreased urinary CCN 2 by $21 \%$ initially $(P<0.05$ versus baseline), with no further attenuation after increasing dose. The continuous reduction in urinary CTGF was $22 \%(P<0.05$ versus baseline). The persistent reduction of the urinary CCN2 excretion by Losartan correlated with a slower rate of decline in GFR, in spite of plasma CCN2 remaining unchanged throughout the study [43]. These data indicate that the relationship of angiotensin II receptor blockade and CCN2 expression and angiotensin II receptor blockade exerts its renoprotective effect partly through reduction of CTGF expression.

3.3. Aldosterone Receptor Blockade-Spironolactone. Aldosterone is regarded as an injurious component of the reninangiotensin-aldosterone system in renal tissue [44]. Aldosterone receptor blockade also provides beneficial effects in patients with early type 2 diabetic nephropathy [45]. The direct relationship of aldosterone and CCN2 expression in diabetic nephropathy had also been studied. And the results showed that aldosterone upregulated the expression of CCN2, type I and type IV collagen production, in a dosedependent manner in cultured mesangial cells (MCs) and proximal tubular cells (PTCs), without affection of TGF- $\beta 1$ gene expression and protein synthesis. Blockade of aldosterone with spironolactone, a nonspecific mineralocorticoid receptor (MR) antagonist, markedly suppressed the production of CCN2 and collagen induced by aldosterone. But inhibition of TGF- $\beta 1$ with neutralizing TGF- $\beta 1$ antibody did not influence aldosterone-induced CCN2 synthesis, which indicated that aldosterone might directly induce $\mathrm{CCN} 2$ overproduction through a TGF- $\beta 1$-independent pathway in cultured MCs and PTCs. Moreover, spironolactone treatment reduced urinary protein and albumin excretion and prohibited the 
TABLE 2: Agents for nonspecific inhibition of CCN2 expression in diabetic nephropathy.

\begin{tabular}{|c|c|c|c|c|}
\hline Agents & Subjects & Treatment plan & Pathway & Outcome \\
\hline Losartan [43] & T1 DN patients & $\begin{array}{l}50,100 \text {, and } 150 \mathrm{mg} / \text { day for } 2 \\
\text { months, then } 100 \mathrm{mg} \text { for } 36 \\
\text { months }\end{array}$ & & $\begin{array}{l}\text { Losartan persistently decreased urinary } \\
\text { CCN2 excretion, which correlated with a } \\
\text { slower rate of decline in GFR }\end{array}$ \\
\hline $\begin{array}{l}\text { Spironolactone } \\
{[46]}\end{array}$ & $\begin{array}{l}\text { MCs, PTCs } \\
\text { T2DM rats }\end{array}$ & $\begin{array}{l}100 \mathrm{nM} \text { for } 24 \mathrm{~h} \text {; } \\
20 \mathrm{mg} / \mathrm{kg} / \text { day, p.o. } \\
\text { for } 8 \text { months }\end{array}$ & $\begin{array}{l}\text { TGF-betal- } \\
\text { independent } \\
\text { pathway }\end{array}$ & $\begin{array}{l}\text { Spironolactone suppressed the production of } \\
\text { CCN2 in MCs, PTCs, and T2DM rat model. } \\
\text { Spironolactone reduced urinary protein and } \\
\text { albumin excretion. }\end{array}$ \\
\hline Fasudil [52] & T1DM rats & $\begin{array}{l}10 \mathrm{mg} / \mathrm{kg} / \text { day } \\
\mathrm{IG} \text { for } 30 \text { days }\end{array}$ & $\begin{array}{l}\text { Rho/Rho-kinase } \\
\text { pathway }\end{array}$ & $\begin{array}{l}\text { Fasudil inhibited CCN2 expression in the } \\
\text { renal cortex of diabetic rats, with no affection } \\
\text { of plasma glucose, blood pressure, and } \\
\text { creatinine clearance in the diabetic rats. } \\
\text { Fasudil suppressed urinary excretion of } \\
\text { albumin. }\end{array}$ \\
\hline Fasudil [54] & HMCs & $\begin{array}{l}\text { HG } 30 \mathrm{mmol} / \mathrm{L} \\
\text { fasudil } 25,50 \text {, and } 100 \mu \mathrm{mol} / \mathrm{L} \\
\text { for } 12,24,36,48 \text {, and } 72 \mathrm{~h}\end{array}$ & $\begin{array}{l}\text { Rho/Rho-kinase } \\
\text { pathway }\end{array}$ & $\begin{array}{l}\text { Fasudil reduced CCN2 mRNA expression and } \\
\text { protein secretion. }\end{array}$ \\
\hline $\begin{array}{l}\text { Fluorofenidone } \\
\text { [65] (AKF-PD) }\end{array}$ & MMC & $\begin{array}{l}\text { TGF- } \beta 1(1 \mathrm{ng} / \mathrm{mL}) \\
\text { fluorofenidone }(2 \mathrm{mM}) \text { for } 24 \\
\text { hours }\end{array}$ & $\begin{array}{l}\text { ERK and p38 } \\
\text { pathways }\end{array}$ & $\begin{array}{l}\text { Fluorofenidone reduced TGF- } \beta 1 \text {-induced } \\
\text { CCN2 expression. }\end{array}$ \\
\hline $\begin{array}{l}\text { Fluorofenidone } \\
\text { [66] (AKF-PD) }\end{array}$ & $\mathrm{HK} 2$ & $\begin{array}{l}\text { TGF- } \beta 1(5 \mathrm{ng} / \mathrm{mL}) \\
\text { AKF-PD } 1 \mathrm{mM}, 2 \mathrm{mM} \\
\text { For } 48 \mathrm{~h}\end{array}$ & $\begin{array}{l}\text { Downregulation of } \\
\text { p-Smad } 2 \text { and } \\
\text { p-Smad3 proteins. }\end{array}$ & $\begin{array}{l}\text { AKF-PD downregulated TGF- } \beta 1 \text {-induced } \\
\text { CCN2 expression and attenuated EMT. }\end{array}$ \\
\hline Exendin-4 [73] & HMC & $\begin{array}{l}\text { HG } 30 \mathrm{mmol} / \mathrm{L} \\
\text { Ex-4 } 0.03,0.3 \text {, and } 3 \mathrm{nmol} / \mathrm{L} \\
\text { for } 24 \text { hours }\end{array}$ & cAMP/PKA pathway & $\begin{array}{l}\text { Exendin- } 4 \text { decreased HG-induced the } \\
\text { expression of TGF- } \beta 1 \text { and CCN2. }\end{array}$ \\
\hline $\begin{array}{l}\text { PCB [78] } \\
\text { PCE }[78]\end{array}$ & $\begin{array}{l}\text { HRMC } \\
\mathrm{db} / \mathrm{db} \text { mice }\end{array}$ & $\begin{array}{l}\text { HG }(33 \mathrm{mM}) \\
\text { PCB } 10,20 \mu \mathrm{g} / \mathrm{mL} \text { for } 3 \text { days } \\
10 \mathrm{mg} / \mathrm{kg} \text { PCE, p.o. daily for } 8 \\
\text { weeks. }\end{array}$ & $\begin{array}{l}\text { IL-8-Tyk2-STAT } \\
\text { signaling }\end{array}$ & $\begin{array}{l}\text { PCB suppressed IL-8-instigated CCN2 } \\
\text { expression and collagen IV deposition. } \\
\text { PCE extenuated the expression of TGF- } \beta \text {, } \\
\text { CCN2, and collagen IV in renal tissues, } \\
\text { alleviated glomerulosclerosis and renal } \\
\text { filtration dysfunction, and lessened heavy } \\
\text { proteinuria. }\end{array}$ \\
\hline PCA [79] & HRMC & $\begin{array}{l}\mathrm{HG}(33 \mathrm{mM}) \\
\text { PCB } 10,20 \text {, and } 25 \mu \mathrm{g} / \mathrm{mL} \\
\text { for } 3 \text { days }\end{array}$ & $\begin{array}{l}\text { TGF- } \beta \text {-SMAD signal } \\
\text { NF- } \kappa \text { B signaling } \\
\text { MCP signaling }\end{array}$ & $\begin{array}{l}\text { PCA attenuated HG-induced CCN2 } \\
\text { expression and collagen IV production. } \\
\text { PCA reversed HG-reduced MT-1 MMP and } \\
\text { HG-augmented TIMP-2 expression. } \\
\text { PCA inhibited HG-induced ICAM-1 and } \\
\text { MCP-1 expression. } \\
\text { PCA attenuated renal fibrosis and mesangial } \\
\text { inflammation. }\end{array}$ \\
\hline
\end{tabular}

T1 DN: type 1 diabetes nephropathy; GFR: glomerular filtration rate; MCs: mesangial cells; PTCs: proximal tubular cells; T2DM: type 2 diabetes mellitus; IG: intragastric; HMCs: human mesangial cells; MMC: mouse mesangial cells; HK2: human renal proximal tubular epithelial cells; HRMC: human renal mesangial cells; PCB: purple corn butanol fraction; PCE: extracts of purple corn; PCA: purple corn anthocyanins; MCP-1: monocyte chemoattractant protein-1; ICAM-1: intracellular cell adhesion molecule-1.

glomerulosclerosis which correlated with reduction of CCN2, type I and type IV collagen expression in type 2 diabetes mellitus rat model (Figure 1) [46]. Furthermore, recent clinical trials showed that spironolactone alone effectively decreased proteinuria in microalbuminuric patients with type 1 or type II diabetes [47-49], which was independent of blood pressure [47]. And combination of spironolactone (50 mg/day) with hydrochlorothiazide (25 mg/day) significantly decreased $24 \mathrm{~h}$ urine protein and did not increase serum potassium in type 2 diabetic patients with microalbuminuria [48]. These findings suggest that spironolactone may provide the renal protective role at least partly through downregulating the expression of CCN2 in early diabetic nephropathy.

3.4. Rho Kinase Inhibitors. Recent studies also have shown that the small GTPase Rho and its downstream effector Rho-associated kinases (ROCKs) played a crucial role in renal disease including diabetic nephropathy, and selective ROCK inhibitors, such as fasudil and Y-27632, attenuated the development of diabetic nephropathy. It was reported that Rho/Rho-kinase pathway correlated with the increase of transforming growth factor-beta (TGF- $\beta$ ) and connective 


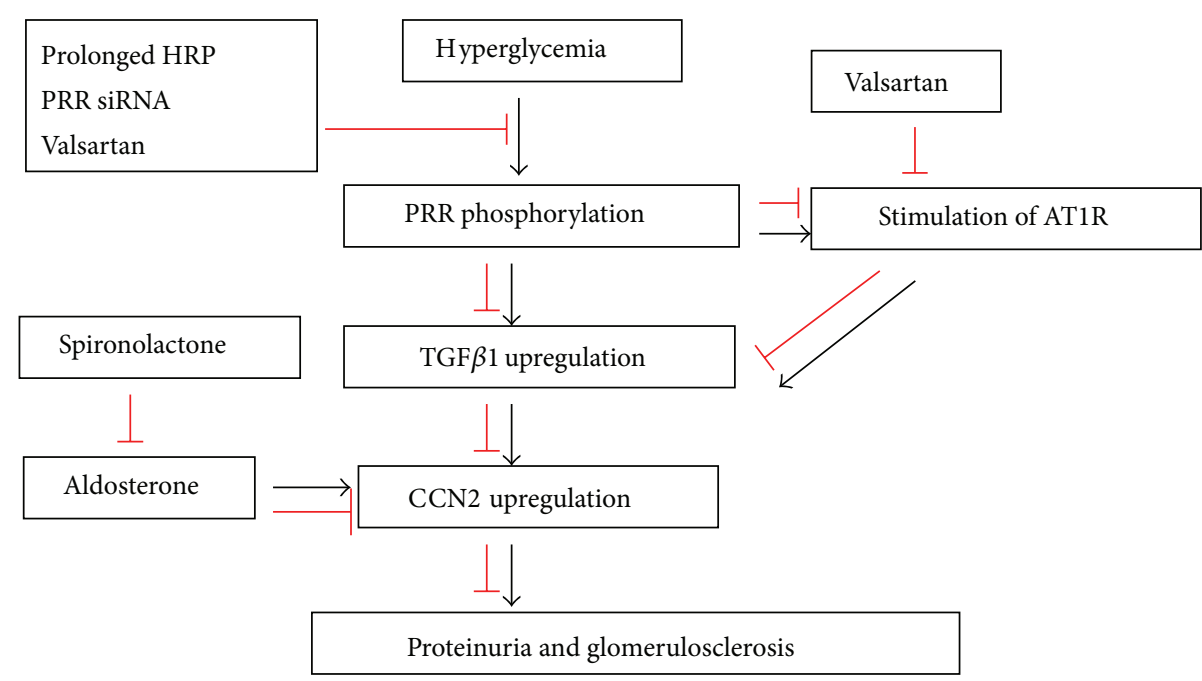

FIGURE 1: Effect of renin-angiotensin-aldosterone system (RAAS) inhibitors on CCN2 expression. Rapid (Pro)renin receptor (PRR) phosphorylation induced by high glucose was prior to upregulation of TGF $\beta 1$ and CCN2, and PRR phosphorylation was inhibited by prolonged handle region peptide (HRP) of prorenin, valsartan, and PRR siRNA treatments, which suggested that TGF $\beta$-CCN2 axis was activated by PRR signaling pathway. Combined treatment with valsartan and PRR siRNA further decreased TGF $\beta 1$ and CCN2 expression, suggesting that AT1R and PRR may independently influence TGF $\beta 1-C C N 2$ axis, or PRR upregulated TGF $\beta 1$ and CCN2 expression by promoting angiotensin II formation and stimulation of AT1R [30]. Aldosterone directly induced CCN2 overproduction through a TGFbetal-independent pathway. Spironolactone markedly suppressed the production of CCN2 induced by aldosterone [46].

tissue growth factor (CCN2) in diabetes, and the RhoA/Rhokinase was activated in diabetic $\mathrm{db} / \mathrm{db}$ mice and rat mesangial cells (MCs) exposed to high glucose [50, 51]. Early administration of selective ROCK inhibitor fasudil significantly suppressed the expression of TGF- $\beta$ and CCN 2 in the renal cortex, attenuated glomerulosclerosis and renal interstitial fibrosis, and decreased urinary albumin excretion [52] without affection on blood glucose or blood pressure in diabetic rats [53]. The reduction of TGF- $\beta$ and CCN2 expression in renal cortex of diabetic rats caused by fasudil suggested that the Rho/Rho kinase pathway was involved in the upregulation of TGF- $\beta$ and CCN2 in diabetic kidney. The in vitro study also demonstrated that fasudil reduced CCN2, $\mathrm{FN}$, and $\mathrm{TNF} \alpha$ protein secretion via suppression the activation of Rho/ROCK signaling pathway and attenuated the inflammation and fibrosis of high glucose-activated HMCs [54]. Taken together, these accumulated findings strongly indicate that RhoA/Rho inhibitors are potential therapeutic agents in the treatment of diabetic renal disease by different mechanisms including inhibition of CCN2.

3.5. Statins. Statins, inhibitor of 3-hydroxy-3-methylglutaryl CoA reductase, are widely administered to control blood cholesterol levels clinically. Some studies have demonstrated that statins played renoprotective roles in several glomerular diseases, including DN $[55,56]$. Moreover, administration of simvastatin with the dose of less than cholesterol-lowering $(2 \mathrm{mg} / \mathrm{kg} / \mathrm{d})$ attenuated the progression of the tubulointerstitial fibrosis by reducing the expression of CCN2 and $\alpha$ SMA in renal tubulointerstitium of diabetic nephropathy rats [57]. Furthermore, simvastatin inhibited CCN2 secretion induced by high glucose in cultured human mesangial cells and prohibited HG induced transcription of the
CCN2 promoter in transfected HEK293 cells significantly; the possible mechanism of CCN2 transcription inhibition with simvastatin might be due to the inhibition of NF- $\kappa \mathrm{B}$ activation pathways $[58,59]$ or impaired glucose uptake and decreased the intracellular concentrations of D-glucose [60]. But the inhibitory effect of statins on urine and plasma CCN2 was not observed in 405 subjects with/without type 2 diabetes; the putative reasons might be several associated factors involved in the expression of CCN2 [61]. Additionally, simvastatin also significantly decreased albuminuria and mesangial matrix expansion in the kidney cortices of $\mathrm{db} / \mathrm{db}$ mice [50]. Overall, statins might be a renoprotective drug partly via the inhibition of CCN2 expression.

3.6. Mycophenolate Mofetil. Mycophenolate mofetil (mycophenolate mofetil, MMF) is a new, efficient immunosuppressor. MMF plays its role of immunosuppression mainly by noncompetitive and reversible inhibition of the rate-limiting enzyme-inosine monophosphate dehydrogenase (IMPDH) for de novo purine synthesis to strongly inhibit T, B lymphocyte proliferation. Thus MMF is more widely used in the treatment of organ transplantation, bone marrow transplantation, and autoimmune diseases. Recent studies have shown that MMF can also be used in treating diabetic nephropathy. MMF reduced protein urine in STZ-induced type-1 diabetic nephropathy model [62]. MMF also decreased the expression of CCN2 in mesangial cells (MCs) exposed to high glucose. The possible mechanism of MPA reduction of CCN2 expression might be that MPA could interfere with G proteinregulated intracellular signal pathway. $G$ protein is activated when GTP is the binding nucleotide; then the downstream signal pathway is switched on. When the binding nucleotide is GDP, G protein is biodeactivated, and the downstream 
signal pathway is shut down. MPA might downregulate the expression of TGF- $\beta$ and CCN2 by reducing intracellular GTP accumulation via suppressing the activity of IMPDH, deactivating most $\mathrm{G}$ protein and blocking intracellular signal pathway [63]. A recent study also demonstrated that the expression of monocyte chemoattractant protein-1 (MCP-1) as well as the secretion of fibronectin (FN) was inhibited by MMF in human mesangial cells (HMCs) exposed to high glucose [64]. These results suggested that MMF played the antifibrotic effect on diabetic nephropathy through suppressing $\mathrm{CCN} 2$ and FN expression.

3.7. Pyridone Agents. Pyridone agents have antifibrotic properties. Fluorofenidone [1-(3-fluorophenyl)-5-methyl-2-(1H)pyridone, AKF-PD], a novel pyridone agent, has shown potent antifibrotic capabilities. AKF-PD significantly reduced TGF- $\beta 1$-induced CCN2 expression in mouse mesangial cells (MMCs). Administration of PD98059 (Erk inhibitor) and SB203580 (P38 inhibitor), respectively, significantly downregulated TGF- $\beta 1$-induced CCN2 expression in mouse mesangial cells (MMCs), suggesting that the downregulation of fluorofenidone on CCN2 expression induced by TGF- $\beta 1$ might be through ERK and p38 pathways [65]. Moreover, fluorofenidone (AKF-PD) also markedly suppressed TGF- $\beta 1$ induced tubular epithelial-mesenchymal transition (EMT) and connective tissue growth factor (CCN2) expression in human proximal tubular epithelial cells (HK2) through blocking TGF- $\beta /$ Smads signaling [66]. In vivo study also showed that fluorofenidone attenuated renal interstitial fibrosis in the rat model of obstructive nephropathy caused by unilateral ureteral obstruction (UUO) through its reduction of the expression of $\alpha$-SMA, TGF- $\beta 1, \mathrm{CCN} 2$, plateletderived growth factor (PDGF), and inhibitor of TIMP1 in the obstructed kidneys [67]. AKF-PD also reduced renal fibrosis and renal dysfunction through decreasing the abnormal accumulation of mesangial matrix by suppressing upregulated expression of TGF- $\beta$ target genes in kidneys of $\mathrm{db} / \mathrm{db}$ mice [68]. This accumulated evidence suggests that pyridone agents are novel treatment approaches by reducing the rate of renal function decline for diabetic nephropathy.

3.8. Glucagon-Like Peptide-1 (GLP-1) Analog-Exendin-4. Exendin-4 is an analog of glucagon-like peptide-1 (GLP1 ), which is a gut incretin hormone and is considered a potential therapeutic drug for type 2 diabetes. Exendin- 4 was firstly isolated from the salivary secretions of the Gila monster lizard [69]. It exerts its glucose-controlling effect by binding to and activating GLP-1 receptor [70], stimulating insulin secretion, inhibiting glucagon secretion, inducing satiety, and delaying gastric emptying [71, 72]. Exendin-4 also exerted potential protective role in diabetic nephropathy by prohibiting high glucose-induced human mesangial cells (HMCs) proliferation and decreasing the expression of TGF$\beta 1$ and CCN2. The intracellular signaling cascade of CCN2 reduction by Exendin- 4 was also investigated by preincubating HMCs with MDL-12330A, a specific adenylyl cyclase inhibitor, and PKI14-22, a specific protein kinase A (PKA) inhibitor, and the results showed that MDL-12330A and
PKI14-22 markedly reversed the inhibitory effect of Exendin4 on TGF- $\beta 1$ and CCN2 mRNA, respectively, suggesting the inhibitory effect of Ex-4 on TGF- $\beta 1$ mRNA and CCN2 mRNA partly via the cAMP/PKA pathway [73]. The in vivo study demonstrated that intraperitoneal administration of Exendin- $4(1 \mathrm{nmol} / \mathrm{kg} /$ day $)$ to $\mathrm{db} / \mathrm{db}$ mice for 8 weeks significantly attenuated glomerular hypertrophy, mesangial matrix expansion, TGF- $\beta 1$ expression, type IV collagen accumulation, and associated glomerular lipid accumulation, together with fewer infiltrating inflammatory cells and apoptotic cells in the glomeruli, which indicated the therapeutic role of Exendin-4 in type 2 diabetic nephropathy [74]. Although several animal studies reported that GLP-1 receptor agonists have protective roles in diabetic nephropathy independent of their glucose-lowering effect, another report elucidated that exenatide should not be administered in patients with severe renal impairment or end stage renal disease [75]. Therefore, further research is needed to investigate the role of glucagonlike peptide-1 (GLP-1) anolog in diabetic nephropathy.

3.9. Purple Corn Anthocyanins (PCA). Purple corn, rich in anthocyanins, has been considered as a functional food and holds potential disease-preventive properties in diabetes and diabetic complications. It was reported that dietary purple corn color (PCC) attenuated high fat (HF) diet-induced insulin resistance in mice [76]. In addition, purple corn anthocyanins (PCA) not only ameliorated blood glucose level and HbAlc, but also protected beta cell from cell death in HIT-T15 cell culture and db/db mice [77]. Moreover, recent studies have shown that PCA weakened the fibrosis at least partly via downregulating CCN2 expression in human renal mesangial cells treated with high glucose and $\mathrm{db} / \mathrm{db}$ mice. High glucose promoted cellular expression and secretion of CCN2 in human renal mesangial cells (HRMCs). IL8 is involved in this process. High glucose augmented the production of the chemokine IL-8 in HRMC, leading to Tyk2 phosphorylation and the activation of STAT1 and STAT3 (Tyk2 downstream proteins). However anthocyanin-rich purple corn butanol fraction (PCB) concentration dependently mitigated HG-inflamed the induction of CCN2 and collagen IV secretion. In addition, PCB greatly inhibited high glucose-induced IL-8 secretion and the activation of Tyk2 and STAT1 and STAT3 in mesangial cells. Therefore, HGprovoked glomerular injury of fibrosis caused by mesangial inflammation of IL-8 was activated by Tyk2-STAT signaling pathway. Moreover, the in vivo study revealed that the anthocyanin-rich polyphenolic extracts of purple corn (PCE) supplement to $\mathrm{db} / \mathrm{db}$ mice significantly extenuated the expression of TGF-beta, CCN2, and collagen IV in $\mathrm{db} / \mathrm{db}$ mouse renal tissues. PCE also attenuated plasma glucose level and severe albuminuria. Furthermore, the expressions of nephrin and podocin were inhibited by treating mice with PCE [78]. Another study also revealed that the HGstimulated CCN2 induction in HRMC correlated with TGF$\beta$-SMAD-responsive pathway which was blunted by PCA. PCA dampened HG-promoted SMAD2 phosphorylation and SMAD4 expression and also reversed HG-inhibited SMAD7 expression in HRMCs. In addition, PCA alleviated HGinflamed hyperplasia and CCN2-induced ECM expansion 


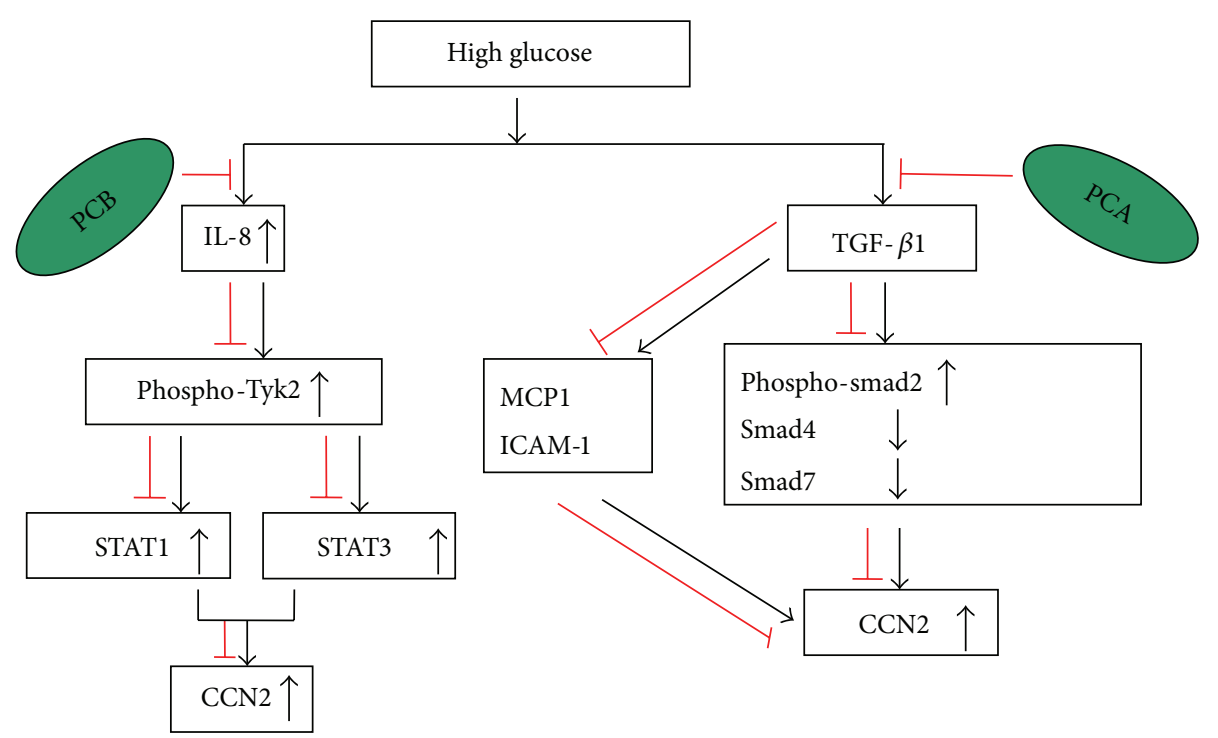

Figure 2: Effect of purple corn anthocyanins (PCA) on CCN2 expression. Anthocyanin-rich purple corn butanol fraction (PCB) concentration dependently mitigated HG-inflamed induction of CCN2. PCB also greatly inhibited HG-induced IL-8 secretion and the activation of Tyk2 and STAT1 and STAT3 in mesangial cells. Therefore, HG-provoked glomerular injury of fibrosis caused by mesangial inflammation of IL-8 was activated by Tyk2-STAT signaling pathway [75]. In addition, HG-stimulated CCN2 induction in human mesangial renal cells (HRMC) correlated with TGF- $\beta$-SMAD-responsive pathways which were blunted by PCA, evidenced by dampening HG-promoted SMAD2 phosphorylation and SMAD4 expression and reversing HG-inhibited SMAD7 expression in HRMCs. Moreover, PCA attenuated TGF- $\beta$-triggered inflammatory ICAM-1 expression and MCP-1 production in the mesangium, leading to the reduction of CCN2 expression [79].

through improving matrix degrading MMP system involving TIMP-2. Moreover, PCA attenuated TGF- $\beta$-triggered inflammatory intercellular cell adhesion molecule-1 (ICAM1) expression and MCP-1 production in the mesangium, leading to the reduction of CCN2 expression (Figure 2). Furthermore, PCA disturbed the crosstalk between TGF$\beta$ and NF- $\kappa$ B signaling which mediated diabetes-associated mesangial inflammation-linked renal fibrosis [79]. Due to the capability of PCA in lessening mesangial inflammationassociated renal fibrosis, PCA seems to be very promising in retarding the progression to diabetic nephropathy.

3.10. Aminoguanidine (AG). Aminoguanidine (AG), a nonspecific inhibitor of advanced glycation end products (AGEs) formation, plays its role by scavenging intermediates in the advanced glycation catalytic process. In the development of DN, AGEs are accumulated and promote the pathological process [80]. Both soluble and matrix bound AGEs upregulated CCN2 expression in cultured human renal mesangial cells $[81,82]$. AGEs also increased the expression of CCN2 in tubular epithelial cells (TECs) [10]. Based on the role of AGEs in CCN2 induction in DN, such anti-AGEs agent as AG has been studied and certified the effect of CCN2 inhibition in experimental diabetic models. It was reported that treatment of diabetic rats with AG prevented the induction of CCN2 at the level of mRNA and protein in the kidneys by suppressing AGEs formation. AG also prevented both AGE and CCN2 immunostaining in the renal cortices of diabetic rats. These data suggest that AG might prevent glomerular damage in diabetes via inhibition of CCN2 [81]. To test whether AG, also known as pimagedine, could attenuate nephropathy in type 1 diabetes mellitus, a randomized, double-masked, placebocontrolled clinical study was performed in 690 patients with type 1 diabetes mellitus, nephropathy, and retinopathy. The final results showed that pimagedine reduced the 24-hour total urinary proteinuria $(P \leq 0.001)$ even though the primary end point was not achieved [83]. But it was also evidenced that aminoguanidine caused DNA damage by free radical production [84]. Therefore, the administration of AG to diabetic nephropathy is restricted considering the safety.

3.11. Tranilast. Tranilast (N-[3,4-dimethoxycinnamoyl]anthranilic acid), a synthetic inhibitor of TGF- $\beta$, has also been administered in the experimental and clinical studies of diabetic nephropathy. It is known that CCN2 interacts with other growth factors involved in diabetes complications such as TGF- $\beta 1$. CCN2 is one of the TGF- $\beta 1$-inducible immediate early genes and acts downstream of TGF- $\beta 1$ [85], participating in TGF- $\beta 1$-induced cell proliferation and ECM synthesis. CCN2 exerts its fibrogenic effects through the TGF- $\beta$ RII in both human proximal tubule cells (PTCs) and cortical fibroblasts (CFs) [86]. Based on the interaction of TGF- $\beta$ and CCN2, anti-TGF- $\beta$ strategies have been carried out in DN. In experimental model of diabetic nephropathy, tranilast was administered and demonstrated to attenuate tubulointerstitial pathology and albuminuria [87]. In PTCs and CFs, tranilast not only decreased TGF- $\beta 1$-induced CCN2 mRNA and phosphorylation of Smad2, but also inhibited CCN2-induced ECM protein and cellular hypertrophy [88]. Furthermore, a small pilot clinical study demonstrated that 
tranilast decreased the decline in glomerular filtration rate in patients with advanced diabetic nephropathy over a 12 month period [89]. All these findings suggest that tranilast is a very promising renal protective compound partly through inhibition of CCN2 in DN.

\section{Conclusions}

Multifactorial pathogenic factors and mechanisms work together and lead to the development and progression of diabetic nephropathy (DN). At present, treatment strategies against DN are mainly focusing on better controlling of blood glucose, blood pressure, and blood lipids, as well as reaching the standard. Even though the patients with diabetic nephropathy have obtained several benefits from the current treatments, the long-term prognosis remains not satisfactory. Consequently, seeking for new treatment targets or therapeutic agents against diabetic nephropathy is urgently needed.

CCN2, as a profibrotic mediator and a proinflammatory cytokine in the development and progress of $\mathrm{DN}$, has been payed more attention by nephrologists in the past decades. Some specific and nonspecific CCN2 inhibitors addressed in this review have shown potential renoprotective effects and highlight the future of the treatment of diabetic nephropathy. However, we should also realize that different modules in the CCN2 protein serve different functions and their functions are cell types specific in some extent $[90,91]$. In addition, CCN2 mRNA stability is markedly influenced by its polyA tail, which has a pivotal effect on the posttranscriptional regulation of CTGF/CCN2 [92]. These findings enlighten us that treatment strategies targeting on CCN2 protein module or CTGF RNA stability in DN may be promising, and it needs to be undertaken and further investigated in DN. We anticipate that such studies could become reality in human disease and improve the prognosis of $\mathrm{DN}$ in the near future.

\section{Conflict of Interests}

The authors declare that there is no conflict of interests regarding the publication of this paper.

\section{Acknowledgments}

This study was supported in part by the National Natural Science Foundation of China (81170669 to L. Miao) and the Scientific Research Starting-Up Fund for returned overseas students from Human Resources and Social Security Department of Jilin Province (to S. Wang). S. Wang is a recipient of Scholarship under State Scholarship Fund from China Scholarship Council.

\section{References}

[1] P. C. Stafylas, P. A. Sarafidis, A. N. Lasaridis et al., "Costeffectiveness of losartan in diabetic nephropathy: a Greek perspective," Journal of Nephrology, vol. 20, no. 6, pp. 703-715, 2007.
[2] W. C. Burns, S. M. Twigg, J. M. Forbes et al., "Connective tissue growth factor plays an important role in advanced glycation end product-induced tubular epithelial-to-mesenchymal transition: implications for diabetic renal disease," Journal of the American Society of Nephrology, vol. 17, no. 9, pp. 2484-2494, 2006.

[3] D. M. Bradham, A. Igarashi, R. L. Potter, and G. R. Grotendorst, "Connective tissue growth factor: a cysteine-rich mitogen secreted by human vascular endothelial cells is related to the SRC-induced immediate early gene product CEF-10," The Journal of Cell Biology, vol. 114, no. 6, pp. 1285-1294, 1991.

[4] S. Gupta, M. R. Clarkson, J. Duggan, and H. R. Brady, "Connective tissue growth factor: potential role in glomerulosclerosis and tubulointerstitial fibrosis," Kidney International, vol. 58, no. 4, pp. 1389-1399, 2000.

[5] R. Goldschmeding, J. Aten, Y. Ito, I. Blom, T. Rabelink, and J. J. Weening, "Connective tissue growth factor: just another factor in renal fibrosis?” Nephrology Dialysis Transplantation, vol. 15, no. 3, pp. 296-299, 2000.

[6] Y. Ito, J. Aten, R. J. Bende et al., "Expression of connective tissue growth factor in human renal fibrosis," Kidney International, vol. 53, no. 4, pp. 853-861, 1998.

[7] M. Uzumcu, M. F. Al Homsi, D. K. Ball et al., "Localization of connective tissue growth factor in human uterine tissues," Molecular Human Reproduction, vol. 6, no. 12, pp. 1093-1098, 2000.

[8] M. Murphy, C. Godson, S. Cannon et al., "Suppression subtractive hybridization identifies high glucose levels as a stimulus for expression of connective tissue growth factor and other genes in human mesangial cells," The Journal of Biological Chemistry, vol. 274 , no. 9, pp. 5830-5834, 1999.

[9] X.-M. Chen, W. Qi, and C. A. Pollock, "CTGF and chronic kidney fibrosis," Frontiers in Bioscience (Schol Ed), vol. 1, no. 1, pp. 132-141, 2009.

[10] A. C. K. Chung, H. Zhang, Y.-Z. Kong et al., "Advanced glycation end-products induce tubular CTGF via TGF- $\beta$ independent Smad3 signaling," Journal of the American Society of Nephrology, vol. 21, no. 2, pp. 249-260, 2010.

[11] F. Yang, A. C. K. Chung, X. Ru Huang, and H. Y. Lan, "Angiotensin II induces connective tissue growth factor and collagen I expression via transforming growth factor- $\beta$-dependent and -independent Smad pathways: the role of Smad3," Hypertension, vol. 54, no. 4, pp. 877-884, 2009.

[12] X.-M. Chen, W. Qi, and C. A. Pollock, "CTGF and chronic kidney fibrosis," Frontiers in Bioscience-Scholar, vol. 1, no. 1, pp. 132-141, 2009.

[13] S. V. McLennan, X. Y. Wang, V. Moreno, D. K. Yue, and S. M. Twigg, "Connective tissue growth factor mediates high glucose effects on matrix degradation through tissue inhibitor of matrix metalloproteinase type 1: implications for diabetic nephropathy," Endocrinology, vol. 145, no. 12, pp. 5646-5655, 2004.

[14] N. A. Wahab and R. M. Mason, "A critical look at growth factors and epithelial-to-mesenchymal transition in the adult kidney: interrelationships between growth factors that regulate EMT in the adult kidney," Nephron-Experimental Nephrology, vol. 104, no. 4, pp. e129-e134, 2006.

[15] W. C. Burns, P. Kantharidis, and M. C. Thomas, "The role of tubular epithelial-mesenchymal transition in progressive kidney disease," Cells Tissues Organs, vol. 185, no. 1-3, pp. 222231, 2007. 
[16] S. M. Twigg, M. E. Cooper, and M. E. Cooper, "The time has come to target connective tissue growth factor in diabetic complications," Diabetologia, vol. 47, no. 6, pp. 965-968, 2004.

[17] H. Yokoi, M. Mukoyama, K. Mori et al., "Overexpression of connective tissue growth factor in podocytes worsens diabetic nephropathy in mice," Kidney International, vol. 73, no. 4, pp. 446-455, 2008.

[18] T. Turk, J. W. Leeuwis, J. Gray et al., "BMP signaling and podocyte markers are decreased in human diabetic nephropathy in association with CTGF overexpression," Journal of Histochemistry and Cytochemistry, vol. 57, no. 7, pp. 623-631, 2009.

[19] E. Sánchez-López, S. Rayego, R. Rodrigues-Díez et al., "CTGF promotes inflammatory cell infiltration of the renal interstitium by activating NF- $\kappa$ B," Journal of the American Society of Nephrology, vol. 20, no. 7, pp. 1513-1526, 2009.

[20] Y. Ito, J. Aten, T. Q. Nguyen et al., "Involvement of connective tissue growth factor in human and experimental hypertensive nephrosclerosis," Nephron-Experimental Nephrology, vol. 117, no. 1, pp. e9-e20, 2010.

[21] P. Roestenberg, F. A. Van Nieuwenhoven, J. A. Joles et al., “Temporal expression profile and distribution pattern indicate a role of connective tissue growth factor $(\mathrm{CTGF} / \mathrm{CCN}-2)$ in diabetic nephropathy in mice," The American Journal of PhysiologyRenal Physiology, vol. 290, no. 6, pp. F1344-F1354, 2006.

[22] A. Dendooven, K. G. Gerritsen, T. Q. Nguyen, R. J. Kok, and R. Goldschmeding, "Connective tissue growth factor (CTGF/CCN2) ELISA: a novel tool for monitoring fibrosis," Biomarkers, vol. 16, no. 4, pp. 289-301, 2011.

[23] H. Yokoi, M. Mukoyama, A. Sugawara et al., "Role of connective tissue growth factor in fibronectin expression and tubulointerstitial fibrosis," The American Journal of Physiology-Renal Physiology, vol. 282, no. 5, pp. F933-F942, 2002.

[24] H. Okada, T. Kikuta, T. Kobayashi et al., "Connective tissue growth factor expressed in tubular epithelium plays a pivotal role in renal fibrogenesis," Journal of the American Society of Nephrology, vol. 16, no. 1, pp. 133-143, 2005.

[25] H. Yokoi, M. Mukoyama, T. Nagae et al., "Reduction in connective tissue growth factor by antisense treatment ameliorates renal tubulointerstitial fibrosis," Journal of the American Society of Nephrology, vol. 15, no. 6, pp. 1430-1440, 2004.

[26] L. Chen, B.-C. Liu, X.-L. Zhang, J.-D. Zhang, H. Liu, and M.$\mathrm{X}$. Li, "Influence of connective tissue growth factor antisense oligonucleotide on angiotensin II-induced epithelial mesenchymal transition in HK2 cells," Acta Pharmacologica Sinica, vol. 27, no. 8, pp. 1029-1036, 2006.

[27] M. Guha, Z.-G. Xu, D. Tung, L. Lanting, and R. Natarajan, "Specific down-regulation of connective tissue growth factor attenuates progression of nephropathy in mouse models of type 1 and type 2 diabetes," The FASEB Journal, vol. 21, no. 12, pp. 3355-3368, 2007.

[28] A. Neesse, K. K. Frese, T. E. Bapiro et al., "CTGF antagonism with mAb FG-3019 enhances chemotherapy response without increasing drug delivery in murine ductal pancreas cancer," Proceedings of the National Academy of Sciences of the United States of America, vol. 110, no. 30, pp. 12325-12330, 2013.

[29] E. C. Finger, C.-F. Cheng, T. R. Williams et al., "CTGF is a therapeutic target for metastatic melanoma," Oncogene, vol. 33, no. 9, pp. 1093-1100, 2014

[30] H. Lu, K. Kojima, V. L. Battula et al., "Targeting connective tissue growth factor (CTGF) in acute lymphoblastic leukemia preclinical models: anti-CTGF monoclonal antibody attenuates leukemia growth," Annals of Hematology, vol. 93, no. 3, pp. 485492, 2014.

[31] Z. Szabó, J. Magga, T. Alakoski et al., "Connective tissue growth factor inhibition attenuates left ventricular remodeling and dysfunction in pressure overload-induced heart failure," Hypertension, vol. 63, no. 6, pp. 1235-1240, 2014.

[32] S. G. Adler, S. Schwartz, M. E. Williams et al., "Phase 1 study of anti-CTGF monoclonal antibody in patients with diabetes and microalbuminuria," Clinical Journal of the American Society of Nephrology, vol. 5, no. 8, pp. 1420-1428, 2010.

[33] G. Nguyen, F. Delarue, C. Burcklé, L. Bouzhir, T. Giller, and J.-D. Sraer, "Pivotal role of the renin/prorenin receptor in angiotensin II production and cellular responses to renin," Journal of Clinical Investigation, vol. 109, no. 11, pp. 1417-1427, 2002.

[34] H. M. Siragy and J. Huang, "Renal (pro)renin receptor upregulation in diabetic rats through enhanced angiotensin AT1 receptor and NADPH oxidase activity," Experimental Physiology, vol. 93, no. 5, pp. 709-714, 2008.

[35] J. Huang and H. M. Siragy, "Regulation of (pro)renin receptor expression by glucose-induced mitogen-activated protein kinase, nuclear factor-kappaB, and activator protein-1 signaling pathways," Endocrinology, vol. 151, no. 7, pp. 3317-3325, 2010.

[36] J. Huang, L. C. Matavelli, and H. M. Siragy, "Renal (pro)renin receptor contributes to development of diabetic kidney disease through transforming growth factor- $\beta 1$ - connective tissue growth factor signalling cascade," Clinical and Experimental Pharmacology and Physiology, vol. 38, no. 4, pp. 215-221, 2011.

[37] L. C. Matavelli, J. Huang, and H. M. Siragy, "(Pro)renin receptor contributes to diabetic nephropathy by enhancing renal inflammation," Clinical and Experimental Pharmacology and Physiology, vol. 37, no. 3, pp. 277-282, 2010.

[38] H. Takahashi, A. Ichihara, Y. Kaneshiro et al., "Regression of nephropathy developed in diabetes by (pro)renin receptor blockade," Journal of the American Society of Nephrology, vol. 18, no. 7, pp. 2054-2061, 2007.

[39] Y.-Y. Fan, H. Kobori, D. Nakano et al., "Aberrant activation of the intrarenal renin-angiotensin system in the developing kidneys of type 2 diabetic rats," Hormone and Metabolic Research, vol. 45, no. 5, pp. 338-343, 2013.

[40] G. Wolf, E. Mueller, R. A. K. Stahl, and F. N. Ziyadeh, "Angiotensin II-induced hypertrophy of cultured murine proximal tubular cells is mediated by endogenous transforming growth factor-beta," The Journal of Clinical Investigation, vol. 92, no. 3, pp. 1366-1372, 1993.

[41] B. C. Liu, L. Chen, J. Sun et al., "Connective tissue growth factor-mediated angiotensin II-induced hypertrophy of proximal tubular cells," Nephron Experimental Nephrology, vol. 103, no. 1, pp. e16-e26, 2006.

[42] X. Ren, G. Guan, G. Liu, and G. Liu, "Irbesartan ameliorates diabetic nephropathy by reducing the expression of connective tissue growth factor and alpha-smooth-muscle actin in the tubulointerstitium of diabetic rats," Pharmacology, vol. 83, no. 2, pp. 80-87, 2009.

[43] S. Andersen, F. A. van Nieuwenhoven, L. Tarnow et al., "Reduction of urinary connective tissue growth factor by Losartan in type 1 patients with diabetic nephropathy," Kidney International, vol. 67, no. 6, pp. 2325-2329, 2005.

[44] R. Rocha, P. N. Chander, K. Khanna, A. Zuckerman, and C. T. Stier Jr., "Mineralocorticoid blockade reduces vascular injury in stroke-prone hypertensive rats," Hypertension, vol. 31, no. 1, part 2, pp. 451-458, 1998. 
[45] A. Sato, K. Hayashi, M. Naruse, and T. Saruta, "Effectiveness of aldosterone blockade in patients with diabetic nephropathy," Hypertension, vol. 41, no. 1, pp. 64-68, 2003.

[46] K. H. Han, Y. S. Kang, S.-Y. Han et al., "Spironolactone ameliorates renal injury and connective tissue growth factor expression in type II diabetic rats," Kidney International, vol. 70, no. 1, pp. 111-120, 2006.

[47] S. E. Nielsen, F. Persson, E. Frandsen et al., "Spironolactone diminishes urinary albumin excretion in patients with type 1 diabetes and microalbuminuria: a randomized placebocontrolled crossover study," Diabetic Medicine, vol. 29, no. 8, pp. e184-e190, 2012.

[48] A. Momeni, M. S. Behradmanesh, S. Kheiri, and M. Karami Horestani, "Evaluation of spironolactone plus hydrochlorothiazide in reducing proteinuria in type 2 diabetic nephropathy," Journal of the Renin-Angiotensin-Aldosterone System, vol. 16, no. 1, pp. 113-118, 2015.

[49] A. Makhlough, Z. Kashi, O. Akha, E. Zaboli, and J. Yazdanicharati, "Effect of spironolactone on diabetic nephropathy compared to the combination of spironolactone and losartan," Nephro-Urology Monthly, vol. 6, no. 1, Article ID e12148, 2014.

[50] V. Kolavennu, L. Zeng, H. Peng, Y. Wang, and F. R. Danesh, "Targeting of RhoA/ROCK signaling ameliorates progression of diabetic nephropathy independent of glucose control," Diabetes, vol. 57, no. 3, pp. 714-723, 2008.

[51] F. Peng, D. Wu, B. Gao et al., "RhoA/rho-kinase contribute to the pathogenesis of diabetic renal disease," Diabetes, vol. 57, no. 6, pp. 1683-1692, 2008.

[52] A. Gojo, K. Utsunomiya, K. Taniguchi et al., "The Rhokinase inhibitor, fasudil, attenuates diabetic nephropathy in streptozotocin-induced diabetic rats," European Journal of Pharmacology, vol. 568, no. 1-3, pp. 242-247, 2007.

[53] R. Komers, T. T. Oyama, D. R. Beard et al., "Rho kinase inhibition protects kidneys from diabetic nephropathy without reducing blood pressure," Kidney International, vol. 79, no. 4, pp. 432-442, 2011.

[54] D. W. Ma, Q. Y. Wang, X. Y. Ma, J. Li, Q. H. Guan, and Y. Fu, "The effect of fasudil via Rho/ROCK signaling pathway on the inflammation and fibrosis in human mesangial cells in high glucose medium.," Zhonghua Nei Ke Za Zhi, vol. 50, no. 7, pp. 580-584, 2011.

[55] V. M. Campese, M. K. Nadim, and M. Epstein, "Are 3-hydroxy3-methylglutaryl-CoA reductase inhibitors renoprotective?" Journal of the American Society of Nephrology, vol. 16, no. 3, pp. S11-S17, 2005.

[56] F. R. Danesh, M. M. Sadeghit, N. Amro et al., "3-Hydroxy-3methylglutaryl CoA reductase inhibitors prevent high glucoseinduced proliferation of mesangial cells via modulation of Rho GTPase/ p21 signaling pathway: implications for diabetic nephropathy," Proceedings of the National Academy of Sciences of the United States of America, vol. 99, no. 12, pp. 8301-8305, 2002.

[57] F.-L. Lin, H.-C. Shen, B. Zhu, and K.-Q. Lin, "Effects of simvastatin on expression of CTGF and $\alpha$-SMA in renal tubulointerstitium of rats with diabetic nephropathy," Zhejiang Da Xue Xue Bao Yi Xue Ban, vol. 39, no. 5, pp. 511-516, 2010.

[58] K. S. Ahn, G. Sethi, M. M. Chaturvedi, and B. B. Aggarwal, "Simvastatin, 3-hydroxy-3-methylglutaryl coenzyme A reductase inhibitor, suppresses osteoclastogenesis induced by receptor activator of nuclear factor- $\kappa \mathrm{B}$ ligand through modulation of NF- $\kappa$ B pathway," International Journal of Cancer, vol. 123, no. 8 , pp. 1733-1740, 2008.
[59] W. Dichtl, J. Dulak, M. Frick et al., "HMG-CoA reductase inhibitors regulate inflammatory transcription factors in human endothelial and vascular smooth muscle cells," Arteriosclerosis, Thrombosis, and Vascular Biology, vol. 23, no. 1, pp. 58-63, 2003.

[60] A. Malenda, A. Skrobanska, T. Issat et al., "Statins impair glucose uptake in tumor cells," Neoplasia, vol. 14, no. 4, pp. 311323, 2012.

[61] B. Yang, A. D. Hodgkinson, N. A. Shaw, B. A. Millward, and A. G. Demaine, "Protective effect of statin therapy on connective tissue growth factor induction by diabetes in vivo and high glucose in vitro," Growth Factors, vol. 31, no. 6, pp. 199-208, 2013.

[62] R. Utimura, C. K. Fujihara, A. L. Mattar, D. M. A. C. Malheiros, I. D. L. Noronha, and R. Zatz, "Mycophenolate mofetil prevents the development of glomerular injury in experimental diabetes," Kidney International, vol. 63, no. 1, pp. 209-216, 2003.

[63] Y. Lü, J. Chen, and J. Shao, "Effects of mycophenolic acid on high glucose-induced expression of TGF-beta and CTGF in mesangial cells," Journal of Huazhong University of Science and Technology: Medical Sciences, vol. 26, no. 3, pp. 292-304, 2006.

[64] F. Q. Chen, Q. Y. Wang, G. Z. Wei et al., "Effects of mycophenolate mofetil on the expression of monocyte chemoattractant protein-1 and fibronectin in high glucose cultured human mesangial cells," Genetics and Molecular Research, vol. 13, no. 2, pp. 3154-3161, 2014.

[65] L. Wang, G.-Y. Hu, H. Shen, Z.-Z. Peng, W.-B. Ning, and L.J. Tao, "Fluorofenidone inhibits TGF- $\beta 1$ induced CTGF via MAPK pathways in mouse mesangial cells," Pharmazie, vol. 64, no. 10, pp. 680-684, 2009.

[66] Q. Yuan, L. Wang, F. Zhang et al., "Fluorofenidone suppresses epithelial-mesenchymal transition and the expression of connective tissue growth factor via inhibiting TGF- $\beta$ /Smads signaling in human proximal tubular epithelial cells," Die Pharmazie, vol. 66, no. 12, pp. 961-967, 2011.

[67] B. X. Li, Y. T. Tang, W. Wang et al., "Fluorofenidone attenuates renal interstitial fibrosis in the rat model of obstructive nephropathy," Molecular and Cellular Biochemistry, vol. 354, no. 1-2, pp. 263-273, 2011.

[68] L. H. Wang, J. S. Liu, W. B. Ning et al., "Fluorofenidone attenuates diabetic nephropathy and kidney fibrosis in $\mathrm{db} / \mathrm{db}$ mice," Pharmacology, vol. 88, no. 1-2, pp. 88-99, 2011.

[69] J. Eng, W. A. Kleinman, L. Singh, G. Singh, and J.-P. Raufman, "Isolation and characterization of exendin-4, an exendin-3 analogue, from Heloderma suspectum venom: further evidence for an exendin receptor on dispersed acini from guinea pig pancreas," Journal of Biological Chemistry, vol. 267, no. 11, pp. 7402-7405, 1992.

[70] R. Goke, H.-C. Fehmann, T. Linn et al., "Exendin-4 is a high potency agonist and truncated exendin-(9-39)-amide an antagonist at the glucagon-like peptide 1-(7-36)-amide receptor of insulin-secreting $\beta$-cells," Journal of Biological Chemistry, vol. 268, no. 26, pp. 19650-19655, 1993.

[71] D. J. Drucker, “The biology of incretin hormones," Cell Metabolism, vol. 3, no. 3, pp. 153-165, 2006.

[72] J. J. Holst, "Glucagon-like peptide-1: from extract to agent. The Claude Bernard Lecture, 2005," Diabetologia, vol. 49, no. 2, pp. 253-260, 2006.

[73] W. Li, M. Cui, Y. Wei, X. Kong, L. Tang, and D. Xu, "Inhibition of the expression of TGF- $\beta 1$ and CTGF in human mesangial cells by exendin-4, a glucagon-like peptide-1 receptor agonist," Cellular Physiology and Biochemistry, vol. 30, no. 3, pp. 749-757, 2012. 
[74] C. W. Park, H. W. Kim, S. H. Ko et al., "Long-term treatment of glucagon-like peptide-1 analog exendin- 4 ameliorates diabetic nephropathy through improving metabolic anomalies in $\mathrm{db} / \mathrm{db}$ mice," Journal of the American Society of Nephrology, vol. 18, no. 4, pp. 1227-1238, 2007.

[75] T. D. Filippatos and M. S. Elisaf, "Effects of glucagon-like peptide-1 receptor agonists on renal function," World Journal of Diabetes, vol. 4, no. 5, pp. 190-201, 2013.

[76] T. Tsuda, F. Horio, K. Uchida, H. Aoki, and T. Osawa, "Dietary cyanidin 3-O-beta-D-glucoside-rich purple corn color prevents obesity and ameliorates hyperglycemia in mice," Journal of Nutrition, vol. 133, no. 7, pp. 2125-2130, 2003.

[77] S. H. Hong, J.-I. Heo, J.-H. Kim et al., "Antidiabetic and Beta cell-protection activities of purple corn anthocyanins," Biomolecules \& Therapeutics, vol. 21, no. 4, pp. 284-289, 2013.

[78] J. Li, M.-K. Kang, J.-K. Kim et al., "Purple corn anthocyanins retard diabetes-associated glomerulosclerosis in mesangial cells and db/db mice," European Journal of Nutrition, vol. 51, no. 8, pp. 961-973, 2012.

[79] J. Li, S. S. Lim, J.-Y. Lee et al., "Purple corn anthocyanins dampened high-glucose-induced mesangial fibrosis and inflammation: possible renoprotective role in diabetic nephropathy," Journal of Nutritional Biochemistry, vol. 23, no. 4, pp. 320-331, 2012.

[80] M. E. Cooper, "Pathogenesis, prevention, and treatment of diabetic nephropathy," The Lancet, vol. 352, no. 9123, pp. 213219, 1998.

[81] S. M. Twigg, Z. Cao, S. V. McLennan et al., "Renal connective tissue growth factor induction in experimental diabetes is prevented by aminoguanidine," Endocrinology, vol. 143, no. 12, pp. 4907-4915, 2002.

[82] X. Wang, S. V. McLennan, and S. M. Twigg, "CCN-2 is upregulated by and mediates effects of matrix bound advanced glycated end-products in human renal mesangial cells," Journal of Cell Communication and Signaling, vol. 5, no. 3, pp. 193-200, 2011.

[83] W. K. Bolton, D. C. Cattran, M. E. Williams et al., "Randomized trial of an inhibitor of formation of advanced glycation end products in diabetic nephropathy," American Journal of Nephrology, vol. 24, no. 1, pp. 32-40, 2004.

[84] G. Suji and S. Sivakami, "DNA damage by free radical production by aminoguanidine," Annals of the New York Academy of Sciences, vol. 1067, no. 1, pp. 191-199, 2006.

[85] A. Igarashi, H. Okochi, D. M. Bradham, and G. R. Grotendorst, "Regulation of connective tissue growth factor gene expression in human skin fibroblasts and during wound repair," Molecular Biology of the Cell, vol. 4, no. 6, pp. 637-645, 1993.

[86] W. Qi, S. Twigg, X. Chen et al., "Integrated actions of transforming growth factor- $\beta 1$ and connective tissue growth factor in renal fibrosis," American Journal of Physiology-Renal Physiology, vol. 288, no. 4, pp. F800-F809, 2005.

[87] S. Mifsud, D. J. Kelly, W. Qi et al., "Intervention with tranilast attenuates renal pathology and albuminuria in advanced experimental diabetic nephropathy," Nephron. Physiology, vol. 95, no. 4, pp. p83-p91, 2003.

[88] W. Qi, X. Chen, S. Twigg, T. S. Polhill, R. E. Gilbert, and C. A. Pollock, "Tranilast attenuates connective tissue growth factor-induced extracellular matrix accumulation in renal cells," Kidney International, vol. 69, no. 6, pp. 989-995, 2006.

[89] J. Soma, T. Sugawara, Y.-D. Huang, J. Nakajima, and M. Kawamura, "Tranilast slows the progression of advanced diabetic nephropathy," Nephron, vol. 92, no. 3, pp. 693-698, 2002.
[90] G. R. Grotendorst and M. R. Duncan, "Individual domains of connective tissue growth factor regulate fibroblast proliferation and myofibroblast differentiation," The FASEB Journal, vol. 19, no. 7, pp. 729-738, 2005.

[91] R. Rodrigues-Díez, R. R. Rodrigues-Díez, S. Rayego-Mateos et al., "The C-terminal module IV of connective tissue growth factor is a novel immune modulator of the Th17 response," Laboratory Investigation, vol. 93, no. 7, pp. 812-824, 2013.

[92] S. Kondo, S. Kubota, Y. Mukudai et al., "Hypoxic regulation of stability of connective tissue growth factor/CCN2 mRNA by $3^{\prime}$ untranslated region interacting with a cellular protein in human chondrosarcoma cells," Oncogene, vol. 25, no. 7, pp. 1099-1110, 2006. 


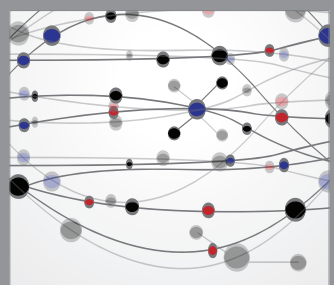

The Scientific World Journal
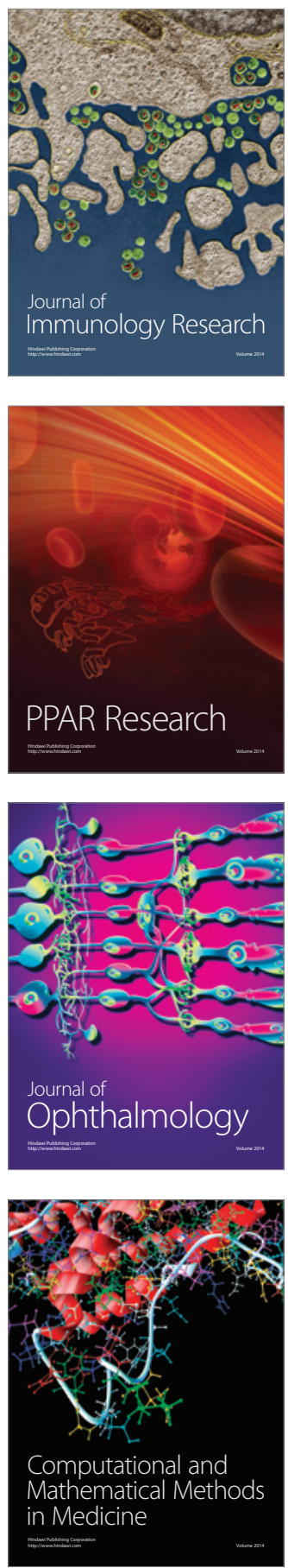

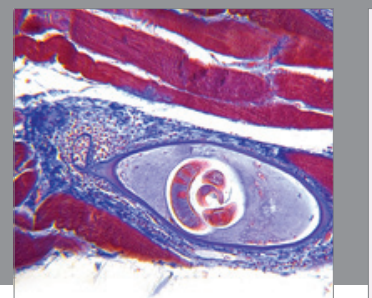

Gastroenterology

Research and Practice
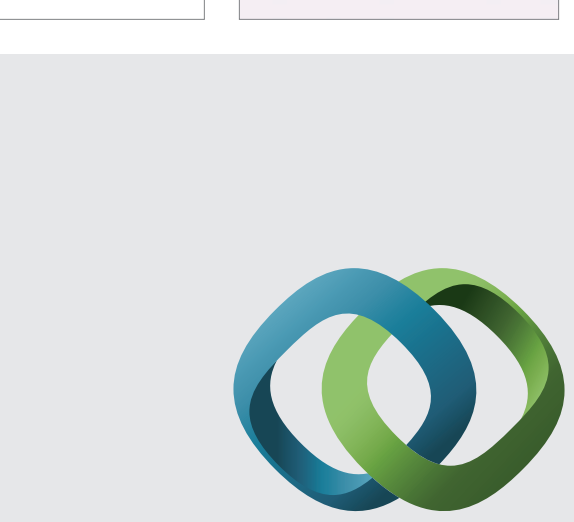

\section{Hindawi}

Submit your manuscripts at

http://www.hindawi.com
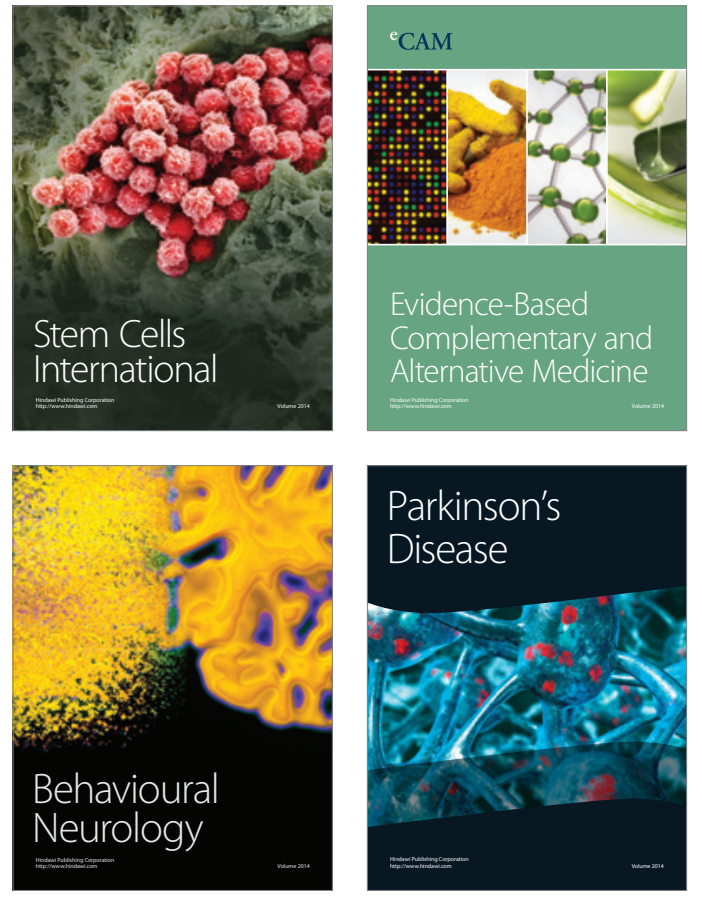
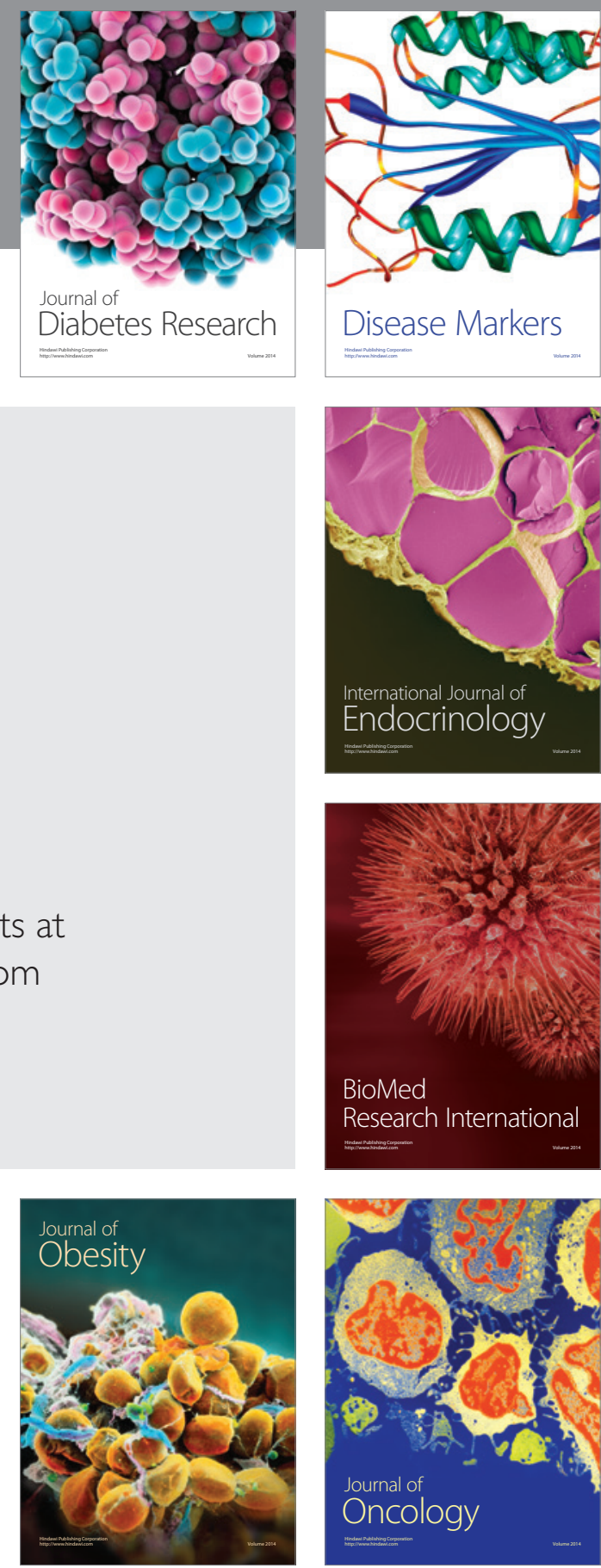

Disease Markers
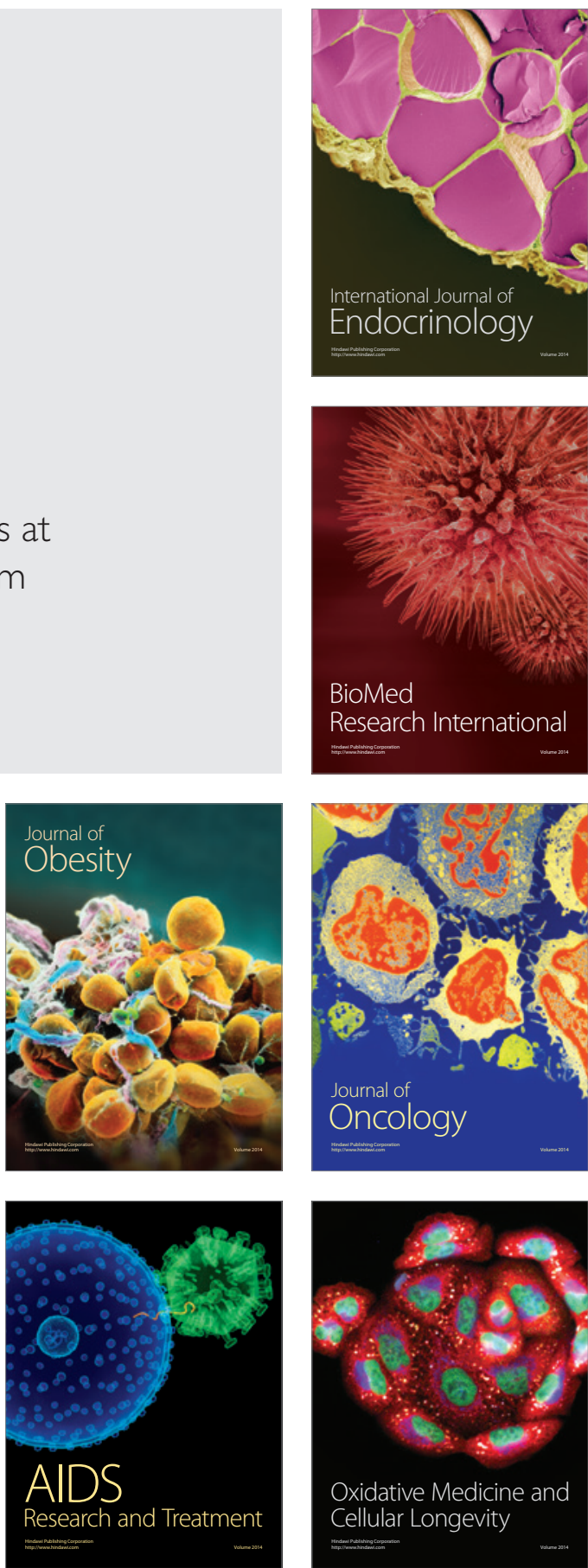